\title{
The Obligation to Migrate and the Impulse to Narrate: Soviet Narratives of Forced Migration in the Nineteenth Century Caucasus
}

\author{
Rebecca Ruth Gould
}

In the year 622/3, ten years after he first heard the Qur'an recited to him, Muhammad was made an offer he could not refuse. The Quraysh of Mecca, a city where he had passed most of his life, had grown hostile to him on account of the popularity of his teachings with the poor, women, and other disenfranchised members of society. Muhammad's calls for social justice and purity of worship were perceived as a threat to the social order. The Meccan elite in particular saw Muhammad's growing popularity as a threat to their power. When the residents of nearby Yathrib offered Muhammad a sanctuary if he wished to relocate there, he agreed, on three conditions. First, he insisted that all of his followers, including his family, would be welcome to migrate to this new city. Second, that all the migrants would be given food and a place to sleep until they were able to look after themselves. Third, that he and his companions would become full-fledged citizens of Yathrib, so that if any of them were attacked by the Meccans, all of Yathrib would come to their defense.

Muhammad's stipulations were accepted and the migration began. So as not to arouse suspicion among the Meccans who preferred to see him and his followers harmed than to leave their city peacefully, the movement was gradual. As for Muhammad himself, after all of his followers had arrived safely in Yathrib, he escaped Mecca in the middle of the night accompanied by Abū Bakr, having spent three days in a cave in order to evade a plot to kill him. Throughout Islamic history, the narration of these events, well known to every Muslim in countless variations, has served as a perpetual reminder that conversion meant abandoning "one's home in order to fight for the cause" because "salvation lay in going forth for heroic ventures and a new world ahead, not patiently staying by one's fields or camels" (Crone 1994, 383).

Known as the hijra, from the Arabic root meaning "to cut off from friendly association" (Q 4:34) the migration to Yathrib is among the most important events in Islamic history (Watt 1941). In keeping with its allegorical style, the Qur'an makes no mention of the city to which Muhammad and his followers migrated. At the same time, the historical event of the migration is clearly 
reflected in the text, for it abounds in praise of the muhäjirūn (emigrants) and in condemnation of those who did not migrate. "Whoever emigrates for the cause of Allah will find on the earth many spaces and abundance," reads one memorable verse (Q 4:100). By contrast, the angels of death will interrogate those who refuse to migrate. "Was not the earth of Allah spacious [enough] for you to emigrate therein?" (Q 4:97) will be asked of those who, contrary to the example of the Prophet, chose to stay at home. Through such verses, an historical event was rendered as allegory, and the stage was set for later memorializations of Qur'anic stories.

According to Islamic tradition, pious Jews and Christians prophesied $\mathrm{Mu}-$ hammad's hijra long before its occurrence. After conquering Yemen, the Himyarite king Tibān As'ad Abū Karib made his way to the Hijaz with the intention of leveling Yathrib, the city where his son had been killed, to the ground. The king was dissuaded from destroying this town by two Jewish rabbis who warned the king, "if you persist in your intention [to destroy Yathrib], something will happen to prevent your carrying it out and we fear that you will face speedy retribution" (Kitāb Sìrat Rasūl Allāh, ed. Wüstenfeld 1858-6o, 14). At first, the rabbis were hesitant to divulge the reason for their warning. Finally, they explained that Yathrib was designated as the site of a future hijra for a prophet of the Quraysh, and that it would become his home and resting place. The use of the term hijra in this context by Muhammad's biographer Ibn Ishāa (c. 704770) is an anachronism, for the concept of hijra as migration was introduced with Islam. However, Ibn Ishāa's's anachronism is central for grasping the concepts elaborated here, for it demonstrates how, in Islam, hijra is a means through which history is transmuted into cultural memory. It is also an early illustration of the process through which the obligation to migrate has been made coterminous with the impulse to narrate throughout Islamic history.

Further adding to its epoch-making status, the year of the hijra, 622/3, marks the beginning of the Islamic calendar. The migration bisects the two major categories of Quranic revelations, those that were revealed to the prophet in Mecca, which pertain primarily to spiritual matters, and those that were revealed to the prophet in Yathrib, which pertain to politics and ethics. Finally and most importantly, the hijra marks the date when Islam became a religion with an institutional foundation. So long as Muhammad and his followers were based in Mecca, his teachings pertained primarily to personal piety, and could be rejected or accepted at will or in part, without any obvious social consequences. Following the migration, these same teachings came to be endowed with political as well as spiritual import. In recognition of the Prophet's new political orientation, Yathrib's name was changed to Madinat al-nabi ("the city of the prophet") following the arrival of Muhammad and his followers. 
A constitution was drafted and laws were proclaimed (see: Arjomand 2009). Gradually, Islam was coming to be conceived of as a religion of the state, as well as a matter for the soul.

Muhammad's migration from Mecca to Medina was to play an unparalleled role in subsequent Islamic history, as an event in its own right, but particularly as a template for narrating subsequent migrations from lands under non-Muslim rule. At least a century passed before the event itself acquired its singular status, as a paradigmatic story rather than, as in the Qur'an, a perpetually recurring obligation. In its capacity as a narrative trope, the prophet's hijra provided a framework through which trauma and defeat could be made legible. Time and again, the traumatic journey of Muhammad and his muhäjirūn was invoked by Muslim writers to give substance to the geographically and demographically more expansive displacements of later periods of Islamic history, including the Mongol invasions of the thirteenth century and the Spanish Reconquista (1492). Most notably for present purposes, the inaugural hijra from Mecca to Medina shaped local memories of the ethnic cleansings that scarred the former Soviet Union, particularly in the Caucasus, during the 1940s. For the displaced Muslims from the Caucasus discussed in this chapter, the ancient concept of hijra was used to address the traumatic legacies of Soviet deportations.

In its Quranic signification as migration away from a territory that has, whether through conquest or corruption, fallen outside the abode of Islam, hijra is obligatory on all believers. Several hadith attest to its compulsory status. The first, cited by numerous jurists, insists that hijra "will not end until repentance $(t a w b a)$ does, and repentance will not end until the sun rises in the west" (Abū Dāwūd 1995/6: 3: 2479). Another hadith lists hijra among the five commandments that, along with acceptance ( $\left.\operatorname{sam}^{c}\right)$, obedience $\left(\operatorname{ta} a^{\prime} a\right)$, striving (jihād), and unity (jamāca), is obligatory on all believers. (Ibn Hanbal 4: 130) And yet even in the context of these citations, hijra is often understood as a figurative rather than literal migration. As the tenth century jurist Qâdī anNu'mān put it, anyone who has made a journey to Islam (man dakhala fi alislām) is a muhājir (an-Nu'mān 1951, 1194). Another scholar, the Hanafĩ jurist al-Ṭahāwī (843-933), elaborated a concept of a "second hijra [hijrat al-sū']" which the believer can perform while remaining physically at home, at any point in time, and under any type of rule (al-Ṭahāwī, 1533).

Although the division between the muhäjirūn and those who remain behind is lucid in the Qur'an, the ethical and legal meanings of the obligation to migrate have been continuously contested within Islamic political thought. This debate raises questions such as: What constitutes an Islamic territory? How can we know when this territory has ceased to belong to the abode of 
Islam (dār al-islām)? What is the relationship between the abode of unbelief (dār al-kufr) and the abode of faith? These unresolved questions have structured much of Islamic political thought across the centuries. They influence how migration generally, and hijra specifically, has been understood over the course of Islamic history. While serving as a reminder that "salvation lay in going forth for heroic ventures," hijra increasingly became a discourse on the condition of being Muslim in a non-Muslim world, and a commentary on the extent to which the Islamic community (umma) could be spatially imagined and materially mapped. Hijra's meaning has accordingly shifted dramatically across time and space, along with the shifting boundaries of Islamic empires. Many different conceptions of hijra have animated and conditioned religious belief, for, in Muslim-minority societies, the believer's relations with the nonIslamic state substantially shapes the conditions under which the obligation to migrate is performed. These pages offer a perspective on hijra's trans-historical meanings based on nineteenth and twentieth-century sources, while consider its role in the making of literary and cultural history in the Caucasus.

In light of its responsiveness to changes in history, the hijra concept illustrates the internal diversity of Islamic narratives and of Muslim cultural memory. ${ }^{1}$ Patricia Crone calls hijra "one of the rare Islamic notions of which we can unequivocally say that they take us back to the beginnings" (Crone 1994, 383). And yet, even as the concept powerfully evokes Islamic beginnings, it is worth remembering the many radical transformations that hijra has undergone along its journey to the postcolonial present.

At every stage of its development, hijra's meanings have been shaped by the political circumstances within which the concept was implemented, as well as by internal developments within Islamic political and legal thought. With the beginning of Muslim modernity, which almost always transpired under the aegis of colonialism (see Rabbat 2014), the ethical and legal content of the Islamic obligation to migrate underwent a dramatic shift. Whereas the Qur'an interprets the relation between the muhäjirūn and those who remain behind allegorically, scholars during the Ummayad period (661-750) began to understand the hijra as a single event, referring to Muhammad's migration to Medina. Although it could be reenacted and commemorated in many different ways, hijra in this singular meaning could never fully be reproduced.

As the singular event of the hijra became a relic of the past during the Umayyad and particularly Abbasid periods, its contemporaneity faded from

1 Another instructive example of a modern resignification of a Qur'anic concept is fitna (temptation, discord, rebellion), which acquired in later periods of Islamic history an emphasis different from its earliest usages in the Qur’an (see Fisher 1994). 
view. Hijra was transformed from a narrative for the present into a story about the past. In the words of Muhammad's beloved wife 'Āisha, "the believer used to flee with his religion to God and his Messenger, but as for today, God has made Islam victorious, and the believer can worship God wherever he wants" (al-Qāsim 1968, 254). While 'Ā'isha affirmed that the obligation to perform jihād remained, according to this tradition, the obligation to perform hijra had, to all intents and purposes, reached an end.

The dynastic concept of hijra as history prevailed over the Qur'anic concept of hijra as allegory for many centuries. ${ }^{2}$ With the beginnings of modernity, 'Ā'isha's statement that "God has made Islam victorious" resounded with irony, since Islam was anything but victorious in political terms. The declining political status of Islam motivated a turn back to hijra's Qur'anic meaning, as an open-ended and repeating journey incumbent on all believers. In addition to signifying the historical migration to Medina, as it had done since the earliest Islamic beginnings, hijra acquired a new meaning: the obligation to migrate away from lands that had been conquered by non-Muslims, many of which had previously been under Muslim rule. This obligation acquired greater political salience following the conquests by Mongols in the late medieval period, Spaniards in early modernity, and then, most irrevocably, by Russian, British, and French imperial armies and the anticolonial movements these incursions generated during the nineteenth century.

\section{Hijra in the Caucasus}

As a land removed from traditionally Islamic centers of power, the Caucasus did not figure centrally into Islamic legal or ethical discourse on hijra prior to the encounter with colonial modernity. Darband, Tiflis, and Shirwan were destinations for conquest, jihād, not for willed or forced migrations, prior to modernity. In keeping with Muhammad's widely-reported injunction to seek knowledge "even as far as China" (cited in al-Makkī ed. trans. Renard 2004, 119) individual Muslims from the Caucasus did migrate for religious reasons, as they did across the Islamic world. One of the most famous early modern seekers of knowledge was the eighteenth-century scholar Muhammad al-Quduqi, who left Daghestan for Syria due to his frustration with local Muslims who in his view were uncritically imitating the customs of their ancestors

2 By "dynastic" I mean to imply what Crone (1994) calls the "classical" concept of hijra that prevailed in the first century of Islam. For the difference between the conceptualization of hijra in the two periods (also see Madelung 1986). 
and ignoring the precepts of Islam (for al-Quduqi's biography see Gould 2015). When it came to mass migrations, however, and most notably in connection with the Safavid deportations of hundreds of thousands of Georgians and Armenians, mass population movements were organized by the state.

During early modernity, the populations in the Caucasus who experienced the most intensive forced deportation were primarily Christian Georgians and Armenians, not Muslims (Herzig 1990). Colonialism introduced new relations between Muslims and non-Muslims, and, in the Caucasus as elsewhere, these new relations grafted new meanings onto the old concept of hijra. In its various local adaptations, the concept was understood by Muslim and non-Muslim peoples across the Caucasus to signify "the mass migrations of Muslim populations from the Caucasus" (Manning 2012, 145) to Ottoman lands during the nineteenth century. Hijra from the Caucasus radically and permanently altered the demographic makeup of Circassia, Abkhazia, Chechnya, Ingushetia, Georgia, and Daghestan. From Amman to Damascus to Istanbul and all the way to the diasporic communities scattered across North America, the consequences of the colonial era migrations from the Caucasus to Ottoman lands are being lived, and mourned, to this day. (For a comprehensive account of colonial-era hijra, see Bīnū 2007. For recent engagements with these migrations in Anglophone scholarship, see Karny 2000 and Richmond 2013.)

Whereas the inaugural migration from Mecca to Medina is narrated as an act of piety performed under duress, colonial-era migrations from the Caucasus to Ottoman territories were undertaken in response to imperial mandates and threats. In Daghestan, among communities that sustained Islamic textual traditions dating back to the medieval period, the discussion of hijra directly engaged with - and to some extent adapted-Islamic legal theory. Beyond the Daghestani context, hijra more generally came to signify migration away from lands that had fallen under foreign rule. The concept was at once deeply rooted in Islamic traditions and dense with meaning beyond this context, including among Armenian Christian muhäjirs.

By 1864, with the Circassian defeat, the entire Caucasus was officially incorporated into the Russian empire. Immersed as they were in the politics of Ottoman and Russian imperial collusion, the colonial government officials who coordinated and carried out the migrations frequently deceived the target populations concerning the terms of their displacement, and misrepresented the conditions they would face when they reached their destinations. In Soviet-era local literatures, these deceptions were memorialized as violations of the rights and humanity of those who migrated. Defeated mountaineers were forced to migrate and given only two possible destinations: to the Russian interior or to Ottoman lands (Toledano 2009, 83). Through such political 
maneuverings, hijra came for Muslim mountaineers to signify yet one more aspect of coercive colonial rule. Far from evoking the "heroic ventures" with which it was associated in the early days of Islamic expansion, hijra was now a handmaiden of colonial rule.

Pondering the reconfiguration of hijra that coincided with the global decline of Islamic sovereignty and the military ascendency of European empires sheds light on contemporaneous transformations in the Muslim understanding of migration. Looking backwards in time will help clarify the frameworks through which hijra came to signify in modernity. The schools of Islamic law responded to the challenges introduced by the declining fate of Islamic sovereignty in different ways. Given their different approaches to the legal and ethical dimensions of migration, Ḥanafī, Ḥanbalī, Mālikī, and Shāfî̀ interpretations of hijra each merit separate study in the context of their separate geographies. Without assaying a thoroughgoing treatment of hijra across the Islamic world, I will here focus on one specific Shāfi i trajectory, before turning to the literary transformation of hijra memory in Soviet-era depictions of forced migration in the nineteenth-century Caucasus.

\section{$2 \quad$ Hijra as Jihād}

Whereas hijra throughout the Caucasus signified primarily forced migration from the early modern period to Soviet rule, Daghestan presents an important exception to this general pattern. The territory of Daghestan overlapped with the polity in the Caucasus that most successfully withstood colonial rule Imam Shamil's imamate. This state functioned for a quarter of a century, from 18341859, as, among other things, a bulwark against Russian rule. The relative stability of the imamate generated internal splits within the Daghestan community concerning the obligation to migrate to lands under Muslim rule. The jurists in Shamil's service took the position that every Muslim in the region was obliged to migrate to his imamate. To reside outside the imamate was, in this view, to reside in där al-harb (the abode of war). In light of the less stringent understanding of hijra that was dominant in the Shāfi î legal school prevalent in Daghestan, this interpretation appears to represent an innovation, attesting to the new meanings the term acquired during the nineteenth century. And yet, as much as the rigorous, even literalist understanding of hijra was responsive to modern conditions, Daghestani historiography from the period also engaged increasingly with narratives of Islamic beginnings. Alongside reviving its Qur'anic associations, the jurists working under Shamil developed a concept of hijra that was closely bound up with his conception of jihād. 
The poet and jurist Yūsuf al-Yakhsāwī (1795-1871), best known to history as one of Imam Shamil's most articulate opponents, tried to use the Shāfi i understanding of the obligation to migrate to his advantage. (For al-Yakhsāwì's biography, see al-Durgilī 2004: 64/88; al-Ghumūqī 2014: 624-5; al-Qarākhī 1946.) Once, while he was in Mecca for the purpose of performing the hajj, al-Yakhsāwī issued a request for a legal opinion (istifta ${ }^{\top}$ ) to a local mufti concerning the legitimacy of Shamil's imamate. Prior to the formation of the imamate, al-Yakhsāwī recollected that "the people of Daghestan did not live under anybody's power...they were Muslims, and their leaders and judges knew the contents of the book of God, and what had to be done." With the encroachment of the tsar's armies into Daghestan and the simultaneous appearance of a new imam, however, the situation changed. Daghestan was besieged on all sides. The new imam began demanding that Daghestanis must perform hijra by entering the region under his control. Wishing to remain independent of any ruler, al-Yakhsāwī marshaled the resources of Shāfici legal theory to debate the obligation to migrate in a fashion that the new imam would have difficulty contesting:

Do we have to perform hijra?... In our present condition, we are able to live according to our religion, and that we keep to the firm bond of God. This is possible either because we manage to keep apart from the Infidels, for we are a powerful people, or because the Infidels are generous to us, for they fear that we might associate with the muhäjirūn [emigrants, in this case to Shamil's imamate]. Does he who abstains from hijra therefore become an unbeliever? Not performing the hijra is not counted among the things that lead to unbelief. (Kemper 2002: 268) ${ }^{3}$

Al-Yakhsāwì's insistence on the permissibility of living within territories that have fallen under colonial rule was contested by his Meccan correspondent, who, although also a Shāfi ì, was persuaded of the necessity of residing in the core Islamic lands (dār al-Islām), and declared that all Muslims were dutybound to engage in jihād against the infidels rather than to accept peaceful cohabitation with them. Al-Yakhsāwì's interpretation of hijra in terms that legitimated his preference for staying at home was repeated time and again in the nineteenth-century Islamic juridical discourse concerning migration and

3 Arabic manuscript labeled (in Russian): "Letter from Yusuf of Aksai to scholars in Mecca with the request to confirm whether the activity of Imam Shamil conforms to sharia" (Rossiiskaia Akademiia Nauk, Dagestanskii Nauchnyi Tsentr, Institut Istorii, Arkheologii i Etnografiia, Makhachkala, Daghestan), fond 16, op 1, No 174, p 1. Translated in Kemper 2002: 268. 
mobility. Both among scholars who argued for migration and for those who argued for staying behind, banishment from the Islamic community was consistently treated as the greatest tragedy that could befall a Muslim.

Al-Yakhsāwī wished to remain in his native village rather than migrate to Shamil's imamate and become subordinate to what he regarded as its coercive forms of governance. Others did not wish to migrate to Ottoman lands or to Russia's interior. Few Muslims who wished to stay at home saw their wishes honoured. Even when it was not legally mandated, or enforced at the point of a gun, migration was incentivized and often coerced by the colonial state. Mountaineers who remained behind lived to regret their decision, if indeed they lived at all.

Given the region's long history of violent migrations, it is unsurprising that the Caucasus offers a particularly rich set of archives and literatures for the study of migration, and in a range of genres. In Arabic, Russian, Georgian, and Chechen, hijra texts-often invoking this specific term and variations of itnarrate many possible relations between literature and history. Hijra in the Caucasus encompasses the mountains in the north to the lower-lying regions of the south, the defeat of indigenous anticolonial resistance movements during the 185 os and 186os and Daghestan's ill-fated uprising of the 1870s. The term acquired new meanings during the Soviet repressions of minority ethnicities, as well as during their memorialization. Of course, hijra was never a static concept. Yet even a scholar well-versed in its many meanings may be surprised by just how potent and flexible hijra imagery turned out to be over the course of the long nineteenth century.

Colonial-era hijra narratives are primarily in Arabic. They are composed by Muslim scholars who filter their personal experiences and opinions through the prisms of Islamic pasts. Soviet hijra narratives are primarily in Russian and Caucasus vernacular languages, including Georgian, Chechen, and Abkhaz. The nineteenth-century Arabic literature of hijra includes prosimetric autobiography, poetry, and political and legal theory. Soviet Russian and vernacular hijra literature is largely in prose, and includes historical novels that inaugurated their respective literatures. ${ }^{4}$ Diasporic hijra literature, composed by migrants from the Caucasus once they reached their destination, proliferates to this day in Arabic, Russian, English, and French. ${ }^{5}$

Hijra narratives in the Caucasus comprise an internally variegated yet intertextually linked whole. In the process of (re)constructing this literary corpus, I build on prior efforts to develop an anthropological approach to literary

4 An exception to the general tendency toward verse is Galaktion Tabidze's poem, "Muxajiri."

5 In this category, fictional writing such as Idilbī 1991 can be included. 
texts from the Caucasus (Gould 2016). My approach brings migration texts from a range of Caucasus literatures into conversation with each other, and uses these texts to shed light on two centuries of colonization and decolonization in the Caucasus. An anthropological approach to literature enables us to look beyond the construction and deconstruction of canons as literary systems isolated from the broader world, and to understand how texts impact and inflect the worlds to which they refer.

\section{$3 \quad$ Hijra as Banishment}

While hijra was regarded as a singular event in early Islamic history, parallels between the circumstances of Muhammad's migration and the experience of Muslim mountaineers in the aftermath of colonial conquest gave new meaning to the teaching concerning the obligation to migrate. These parallels were reinforced and intensified with repeated narration. As in the age of Muhammad, but in contrast to most of Islamic history, in colonial modernity, the regions to which a Muslim residing in territory under non-Muslim rule could migrate were rapidly contracting. The abode of Islam had radically contracted, and the social infrastructures that facilitated such migrations in prior eras had correspondingly deteriorated.

For Muslims in the nineteenth century Caucasus, hijra meant migration to lands under Ottoman rule, including present day Syria and Jordan, where many Daghestanis and Chechens reside to this day (Bīnū 2007). These lands were vast, but the constellations of power and authority that governed such migrations made them more traumatic than for any preceding period in Islamic history. Whereas hijra was classically an obligation for which the entire Muslim community shared the burden, Ottoman involvement in migrations from the Caucasus was driven by mercenary rather than spiritual concerns. For migrants to Ottoman lands during the colonial period, hijra was less an act of piety which connected them to the wider Islamic community, than a necessity imposed by colonial conquest.

In his Soviet-era reconstruction of these events, the Chechen historical novelist Abuzar Aidamirov (1933-2005) conveys the complex position of the migrants-whom he appropriately calls muhajirs (as the term was rendered in Chechen and Russian) - between Islamic norms and bereavement towards the homeland they were now compelled to abandon after it had come under colonial rule. "A faithful Muslim was performing a pious act—abandoning the land of the giaours," Aidamirov narrates, using the Turkic term for infidel, giaour. Even when these modern Chechen migrants recognize that their 
trauma was prefigured in the life of the Prophet, nonetheless "saying farewell to one's homeland left a tragic impression" (Aidamirov 1996, 409). While narrating these events through the narrative templates afforded by the migration of the Prophet helped migrants connect their plight to the founding narrative of early Islamic history, modern hijras were performed under conditions even more harrowing and more coerced than those undertaken by the Prophet and his companions.

The divided loyalties of the government officials who organized the migrations further complicated the meaning of migration from the Caucasus to Ottoman territories. The enigmatic life and legacy of Musa Kundukhov (1818-1889), who served both the tsar and the Ottoman sultan during successive stages in his career, illustrates these ambiguities well. The son of an Ossetian nobleman (aldar), Kundukhov entered the Pavlovskii Cadet Corps at the age of twelve (Kundukhov 1937). Before he reached the age of twenty, Kundukhov was already working as an interpreter to the Emperor Nicholas during his visit to the Caucasus in 1837. Over the course of the next two decades, this ambitious Ossetian officer rose to the rank of major general in the tsarist army. In 1860, a year following Shamil's surrender and thus of the end of his imamate, tsar Alexandre II (r. 1855-1881) created the Terek province, which included Chechnya and Ingushetia within its domain (figure 9.1). Kundukhov was appointed as the first governor.

During his tenure as a governor, Kundukhov began to make preparations for what would be his most durable and damaging legacy: the forced migration of many thousands of Circassians, Chechens, and Ingush to Ottoman territories. Although the land they were given to live on was, in contrast to the fertile land that they had been promised, barely habitable, the beleaguered mountaineers were powerless to contest decrees that originated in St. Petersburg, or even to ask for what they needed to survive. Although these forced migrations were a disaster for the muhajirs on all counts, they were a success for the tsarist administration, Kundukhov included. After he arrived in the Ottoman empire, Kundukhov soon parted ways with the mountaineers, changed his name to Musa Pasha, and embarked on a career in the sultan's army. Musa Pasha rose high in the ranks of the Ottoman army, and even commanded a battalion against the Russians during the Turko-Russian war of 1877 .

For the early part of his life in the service of the tsar, sources agree concerning the general contours of Kundukhov's biography. It is only after Shamil's surrender, when Kundukhov began to organize mass migrations to the Ottoman empire, that the representation of Kundukhov and his legacy diverges depending on who is telling the story. When Kundukhov's story is told from the vantage point of official Russian sources, the narrative differs starkly from later 


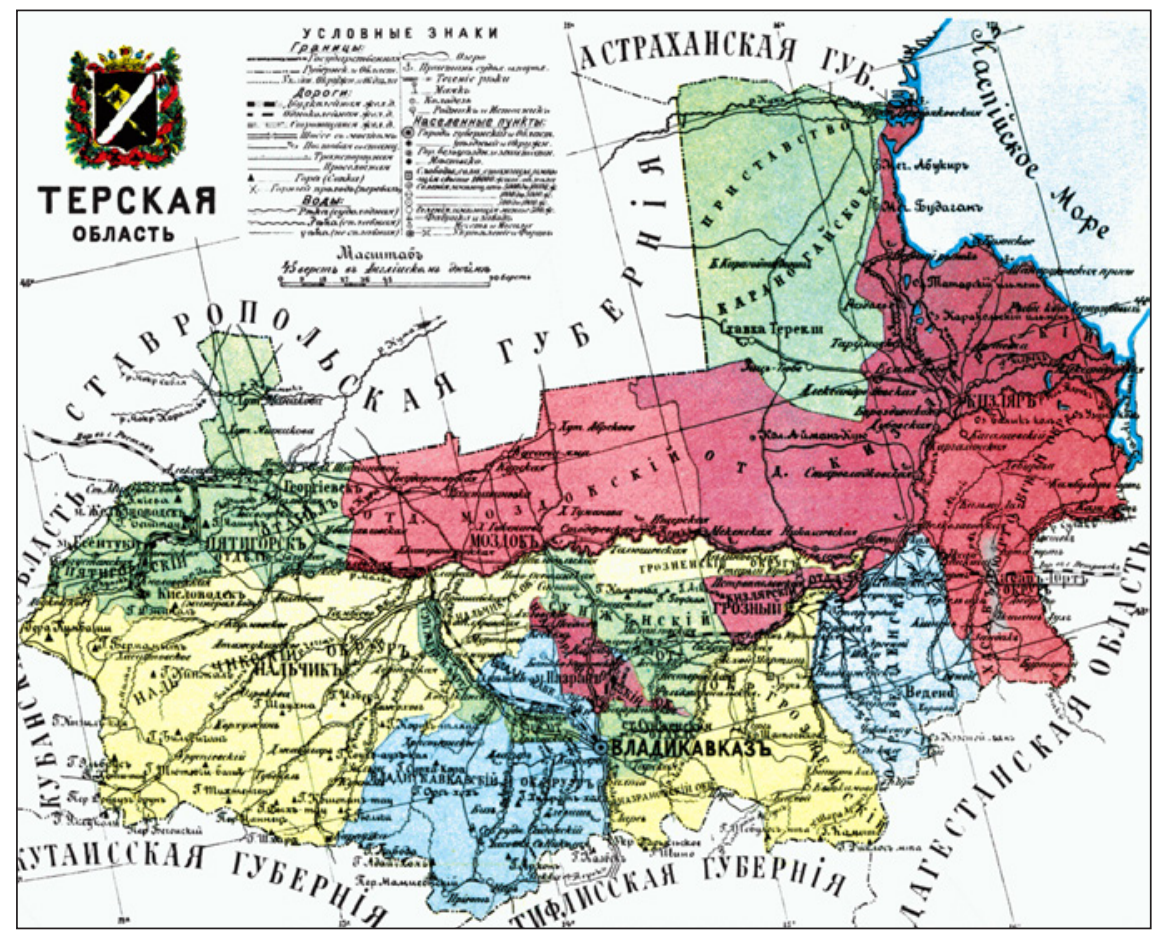

FIGURE 9.1 Map of Terek province

Ingush and Chechen reconstructions. In what, notwithstanding its partiality towards its subject, is among the most detailed accounts of Kundukhov's life on record, Kantemir describes the forced migrations of the 1860s as evidence that "this talented administrator and brave warrior had completely relinquished his political acumen" (Kantemir 1939, 10). Without acknowledging the tragic consequences of his actions or further clarifying their meaning, Allen and Muratoff argue that Kundukhov's organization of the forced migration marked a "break with the Russian authorities" (Allen, Muratoff 1953, 547). Most sympathetic of all is a modern scholarly account that identifies Kundukhov's "disgust with Russian policies towards the local population" as the stimulus behind his campaign for the departure of the mountaineers to Ottoman lands (Khodarkovsky 2011, 4).

If Kundukhov was in fact seeking to rectify the damage done by tsarist policies, it is telling that these noble efforts left no trace in local Caucasus literatures, historiography, or in local memory. In all of these contexts, Kundukhov is remembered in a negative, or at best ambiguous, light. The contemporary Chechen historian Ibragimova has documented in meticulous detail how in 
1861, four years prior to the first major deportation, Kundukhov commandeered an expedition against the Chechen mountaineers that resulted in the destruction of fifteen mountain villages (auls), as well as the massive resettlement of Chechens residing in the mountains onto the plains (Ibragimova 2010). "All of the buildings, in the auls and the homesteads [khutorov] have been burned to their foundations," Kundukhov proudly informed his Russian superiors, "all the hay was charred, not only in the auls, but even in the mountain heights, which surprised the Chechens, who witnessed the conflagration of their inaccessible declivities and lofty heights" (Ibragimova 2010, 295). ${ }^{6}$

Adding to the portrayal of Kundukhov as a perpetrator of injustice, Ibragimova refers to an event in 1845 when Kundukhov publicly shot a Chechen elder who had killed a distant relative of his thirteen years earlier (Ibragimova 2010). As Ibragimova notes, the only punishment Kundukhov faced for this murder was a brief arrest. The colonial administration took the position that "for the sake of peace in the region, it was necessary to treat the event as a matter pertaining [only to] local custom" (Lapin 2008,156). Assessing his overall impact, Ibragimova sums up Kundukhov's legacy as one of "mercenary...careerism" (Ibragimova 2007, 36).

Historians widely acknowledge that Kundukhov acted in tandem with local Chechens who were in the service of the tsar, as when he organized the deportation of twenty-three thousand Chechens to Turkey in 1865 in cooperation with Usmi Saadulla, a former deputy $(n \bar{a} i b)$ in Shamil's imamate (Khojaev 1998,172). Kundukhov also encouraged members of the mountaineer elite to simulate a desire to migrate to Ottoman lands in exchange for bribes, after having promised them secretly that they could return home if they were not pleased by the lands that were allotted to them (Ibragimova 2010). Needless to say, such promises were not extended to the impoverished mountaineers who comprised the vast majority of those forced to migrate. Adding to the irony, a Chechen named Arzu Chermoev - who features widely in subsequent fictional retellings- headed the battalion that destroyed fifteen auls under Kundukhov's command, and which was followed by resettlements (Muzaev 1992,3). Notwithstanding the broad acknowledgement of Chechen complicity by Chechen historians, Kundukhov is consistently treated as a major orchestrator of Chechen's suffering during the nineteenth century, and as the man

6 Otdel rukopisnyh fondov Severo-Osetinskogo instituta gumanitarnyh i social'nyh issledovanii im. V.I. Abaeva (Division of the manuscript section of the North Ossetian Institute of Humanities and Social Research named after V.I. Abaev) f. 33; op. 1; d. 1; 1. 14, 21, 25. Cited in Ibragimova 2010: 295 . 
primarily responsible for the large-scale deceptions that were perpetrated regarding the terms of the proposed migrations.

These ambivalent memories tied to Kundukhov's legacy are even more forcefully evoked in vernacular literary representations of Kundukhov from the Soviet period. Significantly, the two major historical novels of Ingush and Chechen literature, Idris Bazorkin's From the Darkness of Ages (1968) and Aidamirov's aforementioned trilogy (1972-1999) both devote to Kundukhov a degree of space and attention that compares only with the attention lavished on another non-Russian tsarist official, Vorontsov's aide-de-camp the half-Armenian Count Mikhail Tarielovich Loris-Melikov (1826-1888). On both accounts, both Kundukhov and Loris-Melikov were instrumental in organizing the deportations. Bazorkin and Aidamirov however attribute the real agency behind these events to Kundukhov. As they construct an image of Kundukhov as the mastermind behind the mountaineers' tragedy, both novelists emphasize the distance between Kundukhov and the mountaineers. Bazorkin's irony-laden scene in which Kundukhov addresses a pair of Ingush mountaineers, Turs and Goitemir, who have come to plead for the right to access their land, renders this distance through the paradigm of linguistic difference. "I too am a mountaineer," Kundukhov says to a translator, by way of explaining his wealth, and of identifying with the impoverished mountaineers, "I am an Ossetian and a Muslim" (2001, 36). That this heartfelt speech takes place through the medium of a translator, with the self-proclaimed Muslim speaking Russian which the Nakh (the collective term for Chechen and Ingush) can only understand in translation, is indicative of Kundukhov's alienation from his environment.

As soon becomes apparent, Kundukhov's words have a hidden motive. He is trying to persuade his auditors to embark on a hijra to Ottoman lands. He says to his captivated listeners: "I am giving up everything to go to Turkey to live with my Muslim brothers. A man must think not only of his mortal life, but about his eternal life." Kundukhov then divulges his plans to relinquish his wealth in order to migrate to Turkey alongside his fellow mountaineers. Manipulating the spiritual, ethical, and legal discourse of hijra for the political ends of the colonial state, Kundukhov asserts that anyone who refuses to migrate will become "a slave to the tsar" and "will never see paradise," while those who migrate will be blessed with more land than they can harvest. Kundukhov succeeds in persuading at least one of his audience. After he finishes his speech, Turs exclaims gratefully, "Praise Allah! I'm so glad that I met you, Musa... I'll do everything in my power to help you. Thank you for everything."

As readers of the novel soon learn, Turs' gratitude is entirely misplaced. The many promises that were made from both the tsarist and the Ottoman side to the Muslim mountaineers who migrated to Ottoman lands went unfulfilled. 
Instead of fertile land, the migrants were forced to survive on land on which crops could not be sown. Many died from starvation. It is on this juncture in the muhajirs' traumatic history that Aidamirov focuses in his literary treatment of Kundukhov. Whereas Bazorkin portrays Kundukhov from the viewpoint of his mountaineer protagonists, Aidamirov uses internal monologue to depict Kundukhov from within. Writing several years after Bazorkin, Aidamirov delves yet deeper into Kundukhov's enigmatic character, and explores how his desire for good was mixed with a willingness to sacrifice his fellow mountaineers' best interests for the advancement of his career.

Although Kundukhov's father makes no appearance in this or any other Chechen literary text, Aidamirov's chapter on the mastermind behind the migration is entitled "Musa Kundukhov, son of Alxas." In emphasizing his parentage, this label thereby stresses his roots among local mountaineers. The chapter "Musa Kundukhov, son of Alxas," consists mostly of a dialogue between Kundukhov, a Chechen emigrant named Arzu (Chechen for "eagle"), and his Ali. Arzu and Ali were leading a group of Chechens who, having given up on obtaining the land that had been promised, were returning to Chechnya. Although the Chechens knew that they would be stopped at the border by the authorities and forced to turn back, they felt that they had no other option. When Kundukhov crossed paths with the Chechen cavalcade headed for the Ottoman-Russian border, they were prepared to die if they could not make it across.

Although the encounter that subsumes this chapter is narrated primarily through the eyes of the Chechen brothers, Aidamirov's narrative technique polyphonically registers multiple points of view. The scene opens with an unnamed Kundukhov, an officer "dressed in Turkish clothing," whom Ali recognizes immediately as "a Caucasus mountaineer" (551). At this juncture in his rise to power, Kundukhov has become more adept at speaking directly to Chechens, for he addresses Arzu in broken Chechen, asking to speak with the eldest among the group.

Arzu recognizes Kundukhov before Kundukhov recognizes him. Addressing him as "Musa, son of Alxas," Arzu accuses his interlocutor of having a bad memory. By this he means to imply that Kundukhov's culpability has dulled his will to remember. As the modern literature of migration repeatedly affirms, memory acts as an ethical compass. According to this same literature, memory is sustained by an ethical capacity to withstand trauma, and, in the case of the Chechens, to survive. The ethics of memory are forcefully conveyed in Arzu's reflection on why the Chechens are perpetually forgotten by their persecutors. "Everyone tries not to recognize us these days," Arzu says, "Indeed, the executioner does not need to know whom he is decapitating." Following 
this ominous analogy, Arzu concludes with an equally incendiary topic, concerning the arson that Kundukhov perpetrated on fifteen Chechen auls while serving as the governor of the Terek district. In response to Arzu's accusation, Kundukhov launches into a defense of the colonializing project. "It was a bad idea to rise up against the tsar," he declares. "Everyone else submitted to their fate. Only you [Chechens] wanted that crazy freedom [dikii svobodyi]" (552).

In contradistinction to earlier periods of Islamic history, the concepts of freedom and hijra closely converged during the nineteenth and twentieth centuries, amid the struggle against colonial rule and for political autonomy. Whereas hijra originally signified a migration performed under duress but volitionally and in expectation of bigger and better things, the tension between the coercive aspects of the obligation to migrate and the yearning for freedom became evident once the pressure to migrate was imposed by the state rather than by ethical commitment or religious belief. Prior to this transformation, which can be said to have begun with the Reconquista and the expulsion of Muslims from al-Andalus in 1492, hijra was not coercively imposed by the state. As a result of the early modern expulsions, the relationship between hijra and freedom changed. Yet even amid this transformation, earlier hijra narratives appealed to Muslims during the colonial and Soviet periods due to their longstanding, if malleable, association with freedom. The desacralized understanding of hijra that shaped the experience of modern Muslims is apparent from the remark of another of Aidamirov's muhajirs, "Everywhere people are running away from poverty and injustice. It doesn't matter much whether it is the Russian tsar or the Turkish sultan [who causes the injustice]. Everywhere our brothers are being expelled" (416).

Given the tension between hijra and freedom generated by new forms of state coercion in colonial modernity, it is unsurprising that the climactic debate between Kundukhov and the Chechen migrants he encounters on their way back to Chechnya pivots on the issue of freedom, including its dangers and illusions. As a Chechen author, Aidamirov is keenly aware of the prominent status accorded to the concept of freedom in Chechen culture. This reverence for freedom penetrates so deeply that the majority of greetings in the Chechen language are morphologically related in one way or another to marsho, meaning both peace and freedom (Campana 20o9, 45). ${ }^{7}$ Even the word for greetings itself, marshalla, bears this morphological inflection (Jaimoukha 2005, 140). Finally, as the author of the Chechen national anthem which is

7 While Campana 2009 is right to point to the constructed status of Chechen freedom myths, the present example demonstrates that such myths longs predate the post-Soviet conflict and are arguably congruous with Chechen modernity itself. 
included in the novel — a ballad known as "death or freedom" due to its refrain-Aidamirov was well positioned to make this the overriding theme of his text.

In response to Kundukhov's critique of the mountaineers who attempted to resist the tsar's military might, Arzu launches into a defense of freedom, a concept for which he is prepared to die. "Do you know what freedom is?" he asks Kundukhov, "We do. This is why we die for it. We have no regrets, even though [this knowledge] costs us dearly. But when you know what you are dying for, then it's much easier to die" (552). Impressing on Kundukhov the injunction to remember that his experience of banishment has imposed on him, Arzu recalls a statement Kundukhov made after destroying the Chechen auls. At that time, according to Arzu, Kundukhov had promised to never again harm another Chechen. Arzu confronts Kundukhov with the Ossetian proverb he uttered at the time to a group of Chechens that included himself: "when a tree falls, it falls on a neighbor" (535). This means both that the neighbor prevents the tree from falling to the ground as well as that the tree inevitably shoulders the burden of its neighbor's pain. Arzu counters Kundukhov's proverb by accusing Kundukhov of lying. "In order to remind you of your promise," Arzu says, "last winter two people travelled to Skut-Koh. One of them was me."

Tellingly, Kundukhov fails to remember the Chechens' visit, while it is permanently etched on Arzu's consciousness. When Kundukhov confesses, and half apologies for, this failure in his memory on account of the many visits he has received from unhappy muhajirs, Arzu explains what made his reasons for visiting distinct. "We wished to remind you," he states, "that you were obliged to keep your word." Disturbed by these unclaimed memories, Kundukhov deploys a familiar line of defense: he had no other option and was acting according to what he believed were the Chechens' best interests. He claims that the tsar intended to forcibly remove any Chechens who did not migrate to Ottoman lands in the depths of Russia, far from the Caucasus, and compel them, "like sheep, to adopt the [Christian] faith and the [Russian] language" (556). Under such circumstances, Kundukhov stresses, the inevitable outcome would have been genocide. Given that, as he admits, Muslim mountaineers would never agree to the conditions stipulated by the colonial administration, the result would have been war and even more violent banishments of the type that were later to be perpetrated by Stalin. With Kundukhov, colonial discourse merges with an Islamic ethical tradition concerning the obligation to migrate. New meanings are generated and new hypocrisies are forged. 


\section{Conclusion}

Beyond its status as a core teaching and tradition within Islamic law and ethics, hijra is a story, and a method for narrating displacement. The narration of migration as hijra generates a language for grasping the trauma of forced displacement at the global as well as individual level. Much can be gained from inhabiting cognitively the prisms through which the hijra story has been told, from the Maghreb to the Mashreq, from the establishment of the first Islamic state in Medina to the period of dynastic expansion under the Umayyads and the Abbasids to the radical contraction of Muslim sovereignty in early modernity and its obliteration under Russian, French, Spanish, and British colonial rule.

As can be seen from these brief excavations of hijra's meanings across time and space, the obligation to migrate is as variable as Islam itself. Seen from the vantage point of its complex historical trajectory, hijra bridges temporalities, geographies, and peoples. Originating in the severance, of kin from kin, husbands from wives, and of Muslims from non-Muslims, hijra is also paradoxically a unifying concept, a way of living with and through trauma, that gives meaning and structure to the experience of exile and displacement, including, for Chechens, the ongoing experience of the 1944 deportation (Gould 2012). Through the medium of memory, the hijra story is acted out repeatedly, each time with a different meaning yet familiar echoes, varying according to the literature in question, the people whom this literature concerns, and every text's genre and form.

\section{Acknowledgements}

This research was completed with the support of the European Union's Horizon 2020 Research and Innovation Programme under ERC-2017-STG [grant agreement number 759346].

\section{Bibliography}

Aidamirov, Abuzar. 1996. Dolgie Nochi. Moscow: Izd-vo "Agraf."

Arjomand, Saïd Amir. 2009. "The Constitution of Medina: A Sociolegal Interpretation of Muhammad's Acts of Foundation of the Umma," International Journal of Middle East Studies 41(4): 555-575. 
Bazorkin, Idris. 2001. Iz T'my Vekov. Nazran: Seraldo.

Bīnū, Sa'īd. 2007. Al-Shīshān wa-Hïratuhum ilā al-Urdunn (n.p. Amman).

Campana, Aurélie. 20o9. "Collective Memory and Violence: The Use of Myths in the Chechen Separatist Ideology, 1991-1994." Journal of Muslim Minority Affairs 29(1): $43-65$.

Crone, Patricia. 1994. "The First Century Concept of "Hiĝra." Arabica 41(3): 352-387.

Dāwūd, Abū. 1995/6. Sunan Abī Dāwūd. Beirut: Dār al-Kutub al-'Ilmīya.

al-Durgīlī, Nadhīr. 2004. Nuzhat al-Adh-hān fì Tarājim 'Ulamā’ Daghistān. Edited and translated by Michael Kemper and Amir R. Shikhsaidov. Berlin: Klaus Schwarz Verlag.

Fisher, Humphrey. 1994. "Text-Centered Research: Fitna as a Case Study and a Way Forward for Guests in The House of African Historiography." Sudanic Africa 5: $225^{-26}$ o.

al-Ghumūqī. 2014. "Tarājim 'Ulamā̉ Dāghistān," edited and translated by M.A. Musaev as "Biografii dagestanskikh uchyonikh-bogoslovov, protivnikov imama shamiliia," Fundamental'naia issledovanie (6): 624-5.

Gould, Rebecca Ruth. 2012. "Leaving the House of Memory: Post-Soviet Traces of Deportation Memory," Mosaic, A Journal for the Interdisciplinary Study of Literature, 45(2): 149-164.

Gould, Rebecca Ruth. 2015. "Ijtihād Against Madhhab: Legal Hybridity and the Meanings of Modernity in Early Modern Daghestan." Comparative Studies in Society and History, 57(1): 35-66.

Gould, Rebecca Ruth. 2016. Writers and Rebels: The Literatures of Insurgency in the Caucasus. New Haven: Yale University Press.

Herzig, Edmund. 199o. "The Deportation of the Armenians in 1604-1605 and Europe's myth of Shah. Abbas I." Pembroke Papers I: 59-71.

Ibn Ḥanbal. 1984. Musnad. Edited by Aḥmad Muḥammad Shākir. Egypt: Dār al-Ma'ārif.

Ibn Isḥāq. Muḥammad. Kitāb Sīrat Rasūl Allāh. Edited by Ferdinand Wüstenfeld (18586o). Göttingen: Dieterich'sche Universitäts-Buchhandlung.

Ibragimova, Z. Kh. 2007. Chechentsy-XIX vek. Moscow: Probel-20oo.

Ibragimova, Z. Kh. 2010. Chechentsy. Moscow: Probel-20oo.

Idilbī, Ulfat. 1991. Hikāyāt Jaddī: Riwāya. Damascus: Dār al-Talās.

Jaimoukha, Amjad. 2005. The Chechens. New York: Routledge.

Kantemir, A. 1939. Moussa-Pacha Koundoukhov. Les Memoires du general Moussa-Pacha Koundoukhov (1837-1865). Paris: Edition du Caucase.

Karny, Yo'av. 200o. Highlanders: A Journey to the Caucasus in Quest of Memory. New York: Macmillan. 
Kemper, Michael. 2002. "Daghestani Legal Discourse on the Imamate." Central Asian Survey 21(3): $265^{-278 .}$

Khodarkovsky, Michael. 2011. Bitter Choices: Loyalty and Betrayal in the Russian Conquest of the North Caucasus. Ithaca: Cornell University Press.

Khojaev, Dalkhan. 1998. Chechentsiv Russko-Kavkazkoi Voiny. Grozny: Seda.

Kundukhov, M. 1937. "O Vospominaniiakh Musa-Pashi." Kavkaz 8(44): 11-77.

Lapin, VV. 2008. Armiia Rossii v Kavkazskoi voine XVIII-XIX. St Petersburg: Evropeiskii Dom.

Madelung, W. 1986. “Has the Hijra Come to an End?" Revue des Études Islamiques 54: 225-237.

Manning, Paul. 2012. Strangers in a Strange Land Occidentalist Publics and Orientalist Geographies in Nineteenth-century Georgian Imaginaries. Brighton: Academic Studies Press.

Montgomery Watt, William. 1941. "Hidjra," The Encyclopedia of Islam, first edition. Leiden: Brill.

Muzaev, T. 1992. Golos Chechenskoi Respubliki 76.

al-Nu'mān, Qādī. 1951. Da ẩim al-Islām. Edited by Asaf ibn 'Alī Asghar Faidī. Cairo: Dār al-Mac̄rif.

al-Qarākhī, Muhammad Ṭāhir. 1946. Bāriqat al-Suyūf al-Dāghistāniya fì ba'd al-Ghazawāt al-Shāmiliya. Edited by AM. Barabanov and Krachkovskii IG. Moscow: AN sssR. al-Qāsim, Abū 'Ubayd ibn Sallām. 1968. Kitāb al-Amwāl. Edited by Muhammad Khalīl Harrās. Cairo: Maktabat al-Kullīyyāt al-Azharīya.

Rabbat, Nasser. 2014. "Encounters with Modernity in the Arab World," Yale Law School, Occasional Papers, The Dallah Al-Baraka on Islamic Law and Civilization. New Haven: Yale Law School.

Renard, John and Karamustafa, Ahmet T., ed. and trans. 2004. Knowledge of God in Classical Sufism: Foundations of Islamic Mystical Theology. Mahwah, NJ: Paulist Press.

Riabchenko, A.E. 1913. Geograficheskoe opisanie Rossiiskoi Imperii po guberniiam i oblastiam s geograficheskimi kartami. Sankt-Peterburg: Tipografiia "Berezhlivost"- - Rossiia.

Richmond, Walter. 2013. The Circassian Genocide. New Brunswick: Rutgers University Press.

al-Ṭahāwī, Muḥammad. Mushkil al-āthār (1533/1915). Hyderabad: Maṭbacat Majlis Dāirat al-Ma'ārif al-'Uthmānīya.

Toledano, Ehud. 1998. Slavery and Abolition in the Ottoman Middle East. Seattle: University of Washington Press. 